\title{
Pre- and posthatch developmental changes in hypothalamic thyrotropin-releasing hormone and somatostatin concentrations and in circulating growth hormone and thyrotropin levels in the chicken
}

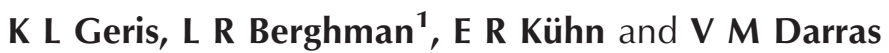 \\ Laboratory of Comparative Endocrinology, Zoological Institute, Catholic University of Leuven, Naamsestraat 61, B-3000 Leuven, Belgium and ${ }^{1}$ Laboratory for \\ Neuroendocrinology and Immunological Biotechnology, Catholic University of Leuven, Naamsestraat 59, B-3000 Leuven, Belgium \\ (Requests for offprints should be addressed to K L Geris)
}

\begin{abstract}
Thyrotropin-releasing hormone (TRH) and somatostatin (SRIH) concentrations were determined by RIA during both embryonic development and posthatch growth of the chicken. Both TRH and SRIH were already detectable in hypothalami of 14-day-old embryos (E14). Towards the end of incubation, hypothalamic TRH levels increased progressively, followed by a further increase in newly hatched fowl. SRIH concentrations remained stable from E14 to E17 and doubled between E17 and E18 to a concentration which was observed up to hatching. Plasma GH levels remained low during embryonic development, ending in a steep increase at hatching. Plasma TSH levels on the other hand decreased during the last week of the incubation.
\end{abstract}

During growth, TRH concentrations further increased, whereas SRIH concentrations fell progressively towards those of adult animals. Plasma TSH levels increased threefold up to adulthood; the rise in plasma GH levels during growth was followed by a drop in adults.

In conclusion, the present report shows that important changes occur in the hypothalamic TRH and SRIH concentration during both embryonic development and posthatch growth of the chicken. Since TRH and SRIH control GH and TSH release in the chicken, the hypothalamic data are compared with plasma GH and TSH fluctuations.

Journal of Endocrinology (1998) 159, 219-225

\section{Introduction}

Both thyrotropin (TSH)-releasing hormone (TRH) and somatostatin (SRIH) are implicated in the control of TSH secretion in the chicken (Lam et al. 1986, Kühn et al. 1987). Besides their effect on the thyroidal axis both hormones also function as potent regulators of growth hormone $(\mathrm{GH})$ secretion in the chicken (Scanes et al. 1981, Harvey et al. 1986, Spencer et al. 1986, Kühn et al. 1988b). These specific actions are already present during embryonic development. The capacity of thyrotropes to respond to TRH administration, measured as an increase in plasma thyroxine $\left(\mathrm{T}_{4}\right)$ concentrations, is already present as early as day 6.5 of incubation (E6.5) (Thommes \& Hylka 1977, Thommes 1987). The GH-releasing activity of TRH is, however, only established around E18 (Kühn et al. 1988a, Darras et al. 1994). The SRIH neuronal system is already fully developed in the hypothalamus before hatching (Blahser \& Heinrichs 1982). Both GH and TSH secretion are inhibited by SRIH at the end of the incubation (Lam et al. 1986, Piper \& Porter 1997).
Because of their nutritional and hormonal independence from the mother, the chick embryo and the posthatch chick are an excellent model to study the ontogeny of hormonal regulation systems. To date, most studies have focussed on changes at the peripheral level - plasma hormone concentrations or in vitro deiodinase activities (Thommes \& Hylka 1977, Hylka et al. 1986, Galton \& Hiebert 1987, Darras et al. 1992). Data on the ontogenetic appearance of hypothalamic factors in the chicken brain are, however, restricted to immunocytochemical studies (corticotropin-releasing hormone (CRH): Josza et al. 1986; TRH: Thommes et al. 1985; SRIH: Ambrosi et al. 1992). Accordingly, this paper describes the ontogenetic profile of hypothalamic TRH and SRIH concentrations during chick embryo development and posthatch growth. These profiles are compared with circulating GH and TSH fluctuations. Due to the lack of specific antibodies to chicken TSH (cTSH) a subtractive strategy was used to obtain an index of plasma TSH concentrations at the different developmental stages studied (Berghman et al. 1993). 


\section{Material and Methods}

\section{Animals}

Chickens (Hisex) used in the different studies were purchased as fertilized eggs from a local commercial dealer (Euribrid, Aarschot, Belgium). Eggs were incubated in a forced-draft laboratory incubator at a temperature of $37 \cdot 8{ }^{\circ} \mathrm{C}$ with increasing humidity and ventilation from day 14 on, with continuous lighting and a $45^{\circ}$ rotation every hour (start of incubation=day 1 (E1)). Posthatch chicks were kept in an acclimated room with a $14 \mathrm{~h}$ light:10 h darkness photoperiod. Adult female chickens (Warren), in the middle of their laying period, were housed individually. Water and feed were freely available The experimental protocols were approved by the ethical committee for animal experiments of the Catholic University, Leuven.

In two independent studies, samples were collected daily during embryonic development starting on day E14. The numbers of animals used in the first study were: E14-E17, $n=30$; E18-E19, $n=20$; E20, $n=30$. Except for E14 and E15 $(n=40)$, the same numbers of animals were used in the second study. On E20 a distinction was made between animals which were not yet entering the air chamber with their beak (non-pipping (NP)) and those which were (internal pipping (IP)), resulting in 15 animals each. The time interval between NP and IP is approximately $6 \mathrm{~h}$. Further sampling occurred on the 21st day of incubation just after hatching $(\mathrm{C} 0=$ chick of zero days old), and on 1-day-old chicks (C1). Eight-day-old and 15-dayold chicks were used. Finally adult chickens were added to the study. In both studies the numbers of animals were: C0-C15, $n=10$; adult, $n=12$. Blood was collected from all animals, by heart puncture in embryonic chicks and by decapitation in posthatch and adult birds. On each occasion the hypothalamic region was separated from the rest of the brain by removing consecutively the telencephalon, the optic lobes, the cerebellum and the brain stem. In the first study TRH concentrations were determined, whereas in the second study SRIH concentrations were analyzed. In the embryonic stages, plasma samples were pooled to ensure completion of each assay. Hypothalamic tissues were pooled similarly to be able to link changes in hypothalamic TRH or SRIH concentrations to plasma hormone fluctuations. This resulted in the first study in 15 samples for the stage E14-E17, in 12 samples for E18-E19 chicks and in 6 samples for E20(NP/IP). The second study contained 11 (E14-E15 and E17-E19), 10 (E16), 8 $(\mathrm{E} 20(\mathrm{NP}))$ or $12(\mathrm{E} 20(\mathrm{IP}))$ samples per embryonic age studied. Posthatch, individual samples were used in both studies.

\section{Extraction of TRH or SRIH}

Hypothalamic regions were weighed and immersed in methanol $(1 \mathrm{ml})$, homogenized and centrifuged at
$3000 \mathrm{~g}$ for $10 \mathrm{~min}\left(4^{\circ} \mathrm{C}\right)$. Supernatants were collected and evaporated by vacuum centrifugation (Speed Vac Concentrator, Savant, NY, USA). For the TRH data, the extracts were dissolved in TRH RIA-buffer $(0 \cdot 14 \mathrm{M} \mathrm{KCl}$, $0 \cdot 1 \mathrm{M} \mathrm{KH}_{2} \mathrm{PO}_{4}, 0 \cdot 01 \%$ merthiolate, $\left.0 \cdot 02 \% \mathrm{BSA}, \mathrm{pH} 7 \cdot 5\right)$. Extraction recovery of known amounts of TRH was $104 \cdot 9 \pm 5 \cdot 3 \%$. For the SRIH data, the extracts were dissolved in SRIH RIA-buffer $\left(0 \cdot 1 \mathrm{M} \mathrm{Na}_{2} \mathrm{HPO}_{4} \cdot 2 \mathrm{H}_{2} \mathrm{O}\right.$, $0.1 \mathrm{M} \mathrm{NaH} \mathrm{PO}_{4} \cdot 2 \mathrm{H}_{2} \mathrm{O}, 0.05 \mathrm{M}$ EDTA, $1 \%$ BSA, $1000 \mathrm{KU}$ Trasylol/ml, pH 7.4). Extraction recovery of known amounts of SRIH was $105 \cdot 5 \pm 13 \cdot 2 \%$.

\section{Radioiodination of TRH}

TRH was iodinated using Chloramine T; $10 \mu \mathrm{l}$ Chloramine $\mathrm{T}(1 \mathrm{mg} / \mathrm{ml})$ were added to $10 \mu \mathrm{TRH}(1 \mathrm{mg} / \mathrm{ml}$ in 0.05 $\mathrm{M}$ phosphate buffer, $\mathrm{pH} 7 \cdot 5), 10 \mu \mathrm{l} 0.5 \mathrm{M}$ phosphate buffer $(\mathrm{pH} 7 \cdot 5)$ and $1 \mathrm{mCi} \mathrm{Na}{ }^{125} \mathrm{I}$. After 2 min the reaction was stopped by addition of $100 \mu \mathrm{l}$ metabisulfite $(1 \mathrm{mg} / \mathrm{ml})$. The radiolabeled peptide was separated from free iodine by rapid filtration on a Sep-Pak C18 cartridge (Pharmacia, Roosendaal, The Netherlands) eluted with $50 \%$ acetonitrile in $0 \cdot 1 \%$ trifluoroacetic acid/water. Further purification of monoiodinated ${ }^{125} \mathrm{I}$-TRH was performed by HPLC on a C4 column $(5 \mu \mathrm{m} ; 120 \times 6 \mathrm{~mm}$, Alltec, Elke, Belgium) using 5\% acetonitrile in $0 \cdot 1 \%$ trifluoroacetic acid/water as eluent. The purified labeled hormone was diluted in TRH RIA buffer.

\section{Radioiodination of SRIH}

SRIH was iodinated using Chloramine T; $5 \mu$ l Chloramine $\mathrm{T}(1 \mathrm{mg} / \mathrm{ml})$ were added to $10 \mu \mathrm{l}\left[\mathrm{Tyr}^{1}\right]-\mathrm{SRIH}$ $(0.5 \mathrm{mg} / \mathrm{ml}$ in $0.01 \mathrm{M} \mathrm{HCl}), 50 \mu \mathrm{l} 0.5 \mathrm{M}$ phosphate buffer $(\mathrm{pH} 7 \cdot 4)$ and $1 \mathrm{mCi}$ of $\mathrm{Na}^{125} \mathrm{I}$. After $30 \mathrm{~s}$ the reaction was stopped by addition of $100 \mu \mathrm{l}$ metabisulfite $(1 \mathrm{mg} / \mathrm{ml})$. The radiolabeled peptide was separated from free iodine by rapid filtration on a Sep-Pak C18 cartridge (Pharmacia) eluted with $80 \%$ acetonitrile in $0 \cdot 1 \%$ trifluoroacetic acid/ water. Further purification of mono-iodinated ${ }^{125} \mathrm{I}-\left[\mathrm{Tyr}^{1}\right]-$ SRIH was performed by HPLC on a C4 column $(5 \mu \mathrm{m}$; $120 \times 6 \mathrm{~mm}$, Alltec) using a linear gradient $(60 \mathrm{~min}$ : from $18 \%$ acetonitrile in $0.1 \%$ trifluoroacetic acid/water to $60 \%$ acetonitrile in $0 \cdot 1 \%$ trifluoroacetic acid/water). The purified labeled hormone was diluted in SRIH RIA buffer.

\section{TRH RIA}

The TRH RIA was carried out according to van Haasteren et al. (1995). Briefly, radioiodinated TRH (15 000 c.p.m./sample), antibody (1/10 $000 \quad(100 \mu \mathrm{l})$, kindly donated by Dr T J Visser, Erasmus University, Rotterdam, The Netherlands), assay buffer and $100 \mu \mathrm{l}$ sample or standard (1.56 to $800 \mathrm{pg}$ ) were incubated in a 
final volume of $400 \mu \mathrm{l}$ in polystyrene tubes for $72 \mathrm{~h}$ at $4{ }^{\circ} \mathrm{C}$. Separation of free and bound radioactivity was achieved by immunoprecipitation using Sac-Cel antirabbit globulin (Innogenetics, Gent, Belgium). After $1 \mathrm{~h}$ incubation at $4{ }^{\circ} \mathrm{C}$ and centrifugation, precipitates were counted in a $\gamma$-counter (Gammamaster, LKB, Pharmacia). The $\mathrm{ED}_{80}$ and the $\mathrm{ED}_{20}$ were respectively 10 and $240 \mathrm{pg}$. The intra- and interassay coefficients of variation were $6 \cdot 6 \pm 0 \cdot 4 \%$ and $15 \cdot 6 \pm 2 \cdot 1 \%$ respectively. Hypothalamic $\mathrm{TRH}$ concentrations were expressed as $\mathrm{pg} / \mathrm{g}$ wet weight.

\section{SRIH RIA}

The SRIH RIA was carried out according to Spencer and co-workers (1991). Antiserum to somatostatin (kindly donated by Dr G S G Spencer, Animal and Grassland Research Institute, Reading, UK) was raised in sheep against a somatostatin-human serum $\alpha$-globulin conjugate (Spencer et al. 1986). On the first day $200 \mu$ antibody $(1 / 40000)$ and $100 \mu \mathrm{l}$ sample or standard $(0.0095$ to $10 \mathrm{ng}$ ) were incubated overnight at $4{ }^{\circ} \mathrm{C}$. After addition of ${ }^{125}$ I-[Tyr $\left.{ }^{1}\right]-S R I H(25000$ c.p.m.) samples were incubated for another $5 \mathrm{~h}$ at room temperature. Separation of free and bound radioactivity was achieved by immunoprecipitation using Sac-Cel anti-sheep globulin (Innogenetics). After $1 \mathrm{~h}$ of incubation at room temperature and centrifugation, precipitates were counted in a $\gamma$-counter (Gammamaster, $\mathrm{LKB}$, Pharmacia). The $\mathrm{ED}_{80}$ and the $\mathrm{ED}_{20}$ were respectively 0.04 and $1.8 \mathrm{ng}$. The intra- and interassay coefficients of variation were $10 \cdot 9 \pm 2 \cdot 3 \%$ and $19 \cdot 0 \pm 2 \cdot 8 \%$ respectively. Hypothalamic SRIH concentrations were expressed as $\mathrm{ng} / \mathrm{g}$ wet weight.

\section{Plasma hormone measurements}

Measurement of circulating chicken GH concentrations was carried out as described before (Darras et al. 1992). Due to the lack of a specific antibody to the $\beta$-subunit of cTSH a subtractive method was used to obtain an index of plasma TSH levels (Berghman et al. 1993). The RIAs of chicken glycoprotein $\alpha$-subunit immunoreactivity and chicken luteinizing hormone (cLH) followed the method described by Berghman et al. (1993). The total titer of $\alpha$-subunit-containing molecules is expressed in relative units $(\mathrm{ru})$. An index of TSH concentrations in the samples is calculated by subtracting cLH values from the concentration of pituitary glycoprotein $\alpha$-subunit of each individual plasma sample. Since chicken follicle stimulating hormone $(\mathrm{cFSH})$ is approximately four times less effective in inhibiting the $(\mathrm{cLH})$ tracer from binding to the anti- $\alpha$ monoclonal antibody, cFSH levels were not included in the subtraction (Berghman et al. 1993). Finally, TSH is expressed in ru since no homologous standard TSH preparations are currently available. This indirect method, validated by Berghman and colleagues (1993), obviously assumes that free $\alpha$-subunit is not being secreted under physiological conditions; measurement of the free $\alpha-$ subunit of pituitary glycoproteins is considered a useful indicator of abnormal hormonal production, for example in pituitary adenomas (Preisner et al. 1990). For all RIAs, chick plasma dilution and loading tests showed a good parallelism with the respective standard curves.

\section{Statistics}

Values represent means \pm S.E.M. Statistical analysis for the ontogenetic studies was by the general linear models of SAS (1985), followed by a Scheffé test. Combined data were used to calculate Pearson correlation coefficients between hypothalamic concentrations and plasma hormone levels (SAS 1985).

\section{Results}

Figure 1 shows hypothalamic TRH concentrations from the last week of the embryonic development towards newly hatched chicks. TRH was already measurable in hypothalami of E14 chicks. From E17 onwards hypothalamic TRH concentrations increased progressively towards the end of embryonic development. At stage E20 no differences were observed when the chicks switched from allantoic respiration (NP) to lung respiration (IP), whereas at hatching hypothalamic TRH concentrations were increased twofold compared with the IP stage. Together with the TRH data, GH and TSH plasma levels are shown in Fig. 1. GH concentrations remained stable at the different embryonic stages, ending with a steep increase at hatching. Plasma TSH levels on the other hand fell from E14 towards hatching. Plasma GH levels were positively correlated with hypothalamic TRH concentrations $(r=0.705 ; P<0.001)$; plasma TSH indices were, on the other hand, negatively correlated $(r=-0.556$; $P<0 \cdot 001$ ).

Changes in the hypothalamic SRIH concentration during embryonic development are shown in Fig. 2. Two distinct areas can be distinguished. At embryonic stages E14-E17 SRIH concentration was stable. Due to a twofold increase between E17 and E18, a second higher plateau was recorded at the end of the incubation (E18-C0). At day 20 no differences were found between NP and IP animals. One-day-old chicks showed a lower hypothalamic SRIH concentration compared with lateembryonic chicks. Plasma GH and TSH profiles were similar to the data from the TRH study; GH levels increased approximately threefold at hatching whereas TSH concentrations dropped progressively towards the end of the incubation (Fig. 2). No correlation was found between the GH and the SRIH data $(r=0 \cdot 166 ; P=0 \cdot 1)$, a negative correlation was observed between plasma TSH and hypothalamic SRIH fluctuations $(r=-0 \cdot 654$; $P<0 \cdot 001)$. 

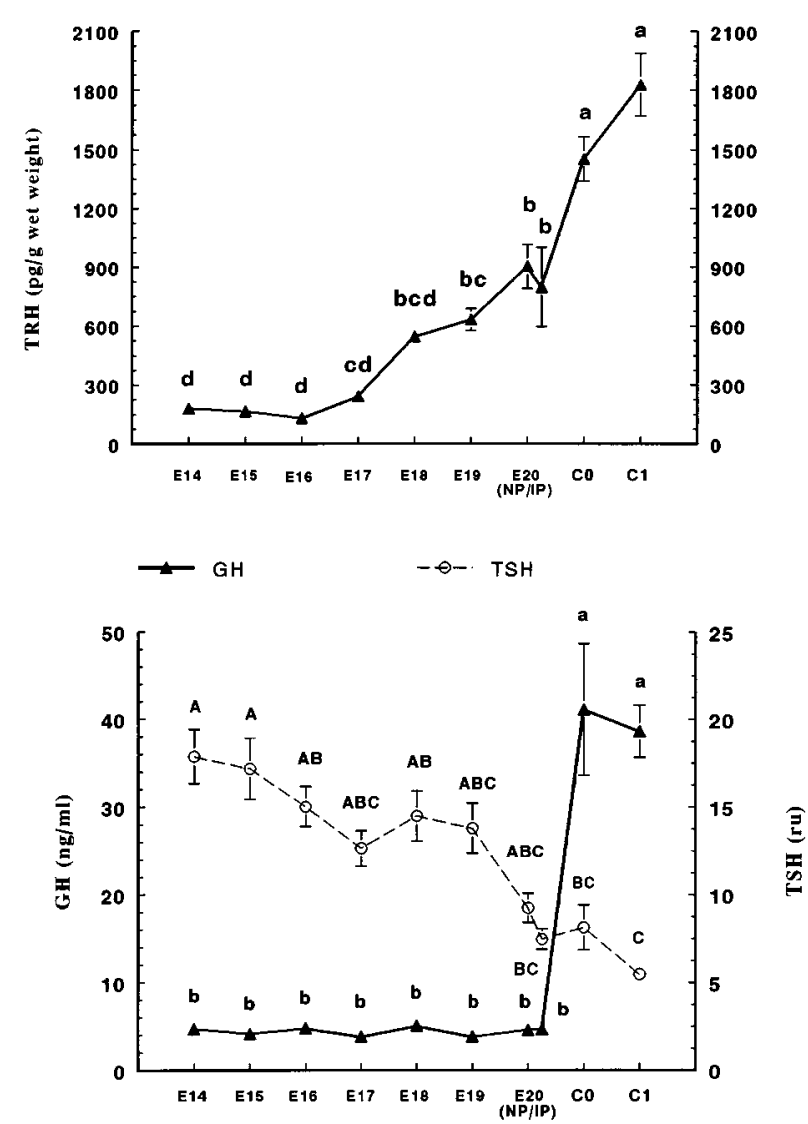

Figure 1 Hypothalamic TRH concentrations (top) and plasma GH and TSH levels (bottom) from the last week of embryonic development to newly hatched chicks. Number of samples for the several developmental stages: E14-E17, $n=15$; E18-E19, $n=12$; E20(NP/IP), $n=6 ; \mathrm{C} 0-\mathrm{C} 1, n=10$. Data are means \pm S.E.M. Within one hormone measurement, data without a common letter are significantly different (Scheffé, $P<0 \cdot 05$ ).

As shown in Table 1, hypothalamic TRH concentrations increased gradually posthatch to reach a maximum in adult chickens. Plasma GH levels increased during growth but dropped in adult birds to GH levels recorded in newly hatched chicks (Table 1). Circulating TSH concentrations increased progressively towards adulthood. These changes in plasma GH and TSH were confirmed in the SRIH study (Table 1). In contrast to the TRH data, hypothalamic SRIH concentrations dropped during growth, resulting in mid-embryonic concentrations in adult animals (Table 1). Plasma GH changes did not correlate with the observed changes in hypothalamic TRH $(r=0 \cdot 203 ; P=0 \cdot 2)$ or SRIH $(r=-0 \cdot 123 ; P=0 \cdot 4)$ concentrations. Plasma TSH indices on the other hand were positively correlated with hypothalamic TRH $(r=0 \cdot 487 ; P<0 \cdot 01)$ and negatively with SRIH $(r=-0 \cdot 351 ; P<0 \cdot 05)$ concentrations.
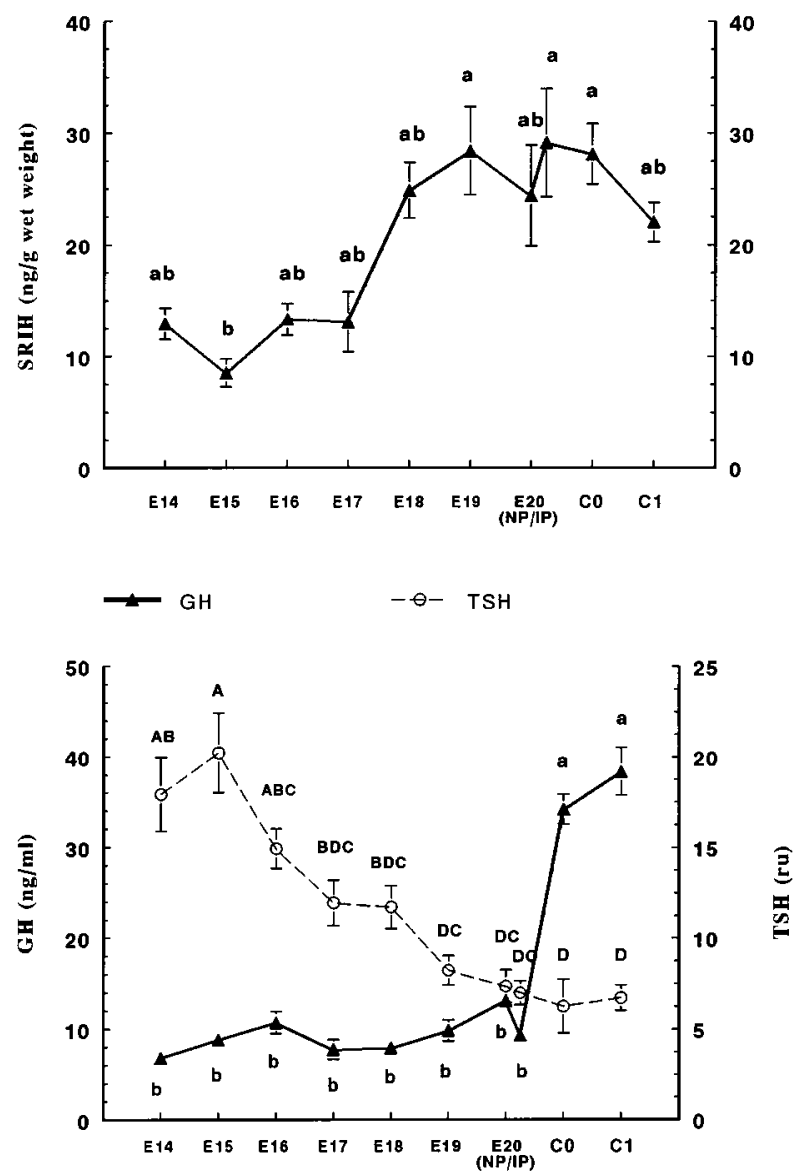

Figure 2 Hypothalamic SRIH concentrations (top) and plasma GH and TSH levels (bottom) from the last week of embryonic development to newly hatched chicks. Number of samples for the several developmental stages: E14-E15 and E17-E19, $n=11 ; \mathrm{E} 16$, $n=10 ; \mathrm{E} 20(\mathrm{NP}), n=8$; E20(IP), $n=12 ; \mathrm{C} 0-\mathrm{C} 1, n=10$. Data are means \pm S.E.M. Within one hormone measurement, data without a common letter are significantly different (Scheffé, $P<0 \cdot 05$ ).

\section{Discussion}

The present results show the profile of hypothalamic TRH and SRIH concentrations during embryonic development and posthatch growth of the chicken. Both peptides were already detected in E14 chicks, the first developmental stage studied. A tenfold increase in hypothalamic TRH concentrations was observed between E14 and 1 day posthatch, whereas SRIH concentrations were only doubled towards the end of incubation. This progressive rise in hypothalamic TRH is in agreement with the gradual increase in both the number of TRH-positive perikarya and in the amount of immunoreactive TRH per cell towards hatching (Thommes et al. 1985). A gradual but less pronounced increase of hypothalamic TRH concentrations was recorded posthatch. Also in mammals hypothalamic TRH concentrations increase before birth 
Table 1 Hypothalamic TRH and SRIH concentrations and plasma GH and TSH levels from newly hatched chickens (C0) up to adult chickens. The numbers of samples per developmental stage are given in parentheses. Two independent studies were conducted. Data shown are means \pm S.E.M.

\begin{tabular}{|c|c|c|c|c|c|c|}
\hline & \multicolumn{3}{|l|}{ Study 1} & \multicolumn{3}{|l|}{ Study 2} \\
\hline & $\begin{array}{l}\text { TRH } \\
\text { (pg/g wet weight) }\end{array}$ & $\begin{array}{l}\mathrm{GH} \\
(\mathrm{ng} / \mathrm{ml})\end{array}$ & $\begin{array}{l}\text { TSH } \\
\text { (ru) }\end{array}$ & $\begin{array}{l}\text { SRIH } \\
\text { (ng/g wet weight) }\end{array}$ & $\begin{array}{l}\mathrm{GH} \\
(\mathrm{ng} / \mathrm{ml})\end{array}$ & $\begin{array}{l}\text { TSH } \\
\text { (ru) }\end{array}$ \\
\hline CO (10) & $1453 \pm 113 c$ & $41 \cdot 2 \pm 7 \cdot 5 b$ & $8 \cdot 1 \pm 1 \cdot 3 b$ & $28 \cdot 1 \pm 2 \cdot 7 a$ & $35 \cdot 2 \pm 1 \cdot 7 b$ & $6 \cdot 3 \pm 1 \cdot 5 c$ \\
\hline C1 (10) & $1829 \pm 158 b c$ & $38 \cdot 7 \pm 3 \cdot 0 b$ & $5 \cdot 5 \pm 0 \cdot 4 b$ & $22 \cdot 0 \pm 1 \cdot 8 a b$ & $38 \cdot 4 \pm 2 \cdot 7 b$ & $6 \cdot 7 \pm 0 \cdot 7 c$ \\
\hline C8 (10) & $2721 \pm 250 b$ & $151 \cdot 2 \pm 23 \cdot 4 a$ & $12 \cdot 7 \pm 2 \cdot 2 a b$ & $16 \cdot 1 \pm 2 \cdot 1 b c$ & $50 \cdot 7 \pm 3 \cdot 5 b$ & $10 \cdot 6 \pm 1 \cdot 6 b c$ \\
\hline
\end{tabular}

Within one hormone measurement, data with a common letter are not significantly different (Scheffé, $P<0 \cdot 05)$.

and continue to rise during growth (Lamberton et al. 1984, Fuse et al. 1991). As to SRIH, concentrations were low in mid-embryonic stages and peaked around hatching, whereas posthatch a gradual decrease was found. Data obtained in the rat revealed an opposite profile; hypothalamic SRIH concentrations do not change during gestation, whereas in the growth period concentrations increase (Jansson et al. 1987).

It is recognized that steady-state measurements of hypothalamic TRH and SRIH cannot be readily related to the release of these secretagogues from the median eminence. Our data nevertheless suggest the maturation of hypothalamic control towards the end of chick embryo development and a higher or lower availability of TRH/ SRIH for secretion into the portal blood system before and after hatching. In mammals, elevations in hypothalamic TRH concentrations during fetal development have been used as an indicator of an increased TRH availability for and increased release towards the pituitary (Oliver et al. 1980, Shambaugh et al. 1983, Nemeskeri et al. 1985). Therefore circulating GH levels were compared with changes in hypothalamic TRH and SRIH concentrations in view of the potent GH-regulating activity of these peptides in the chicken. A positive correlation was found between TRH and GH. The GH increase occurred well after the onset of the TRH increase. This may be linked to the low abundance of fully differentiated, TRH-sensitive somatotropes before day 20 (Dean et al. 1997). As a result a GH response to an in vivo or in vitro TRH challenge is only observed in late embryonic stages (Decuypere \& Scanes 1983, Darras et al. 1994). Since SRIH has an inhibitory effect on GH secretion in the chicken (Harvey et al. 1986), the twofold increase in the SRIH concentration may also form a basis of the late increase in plasma GH levels. The greater overall availability of TRH may in the end result in the higher circulating GH concentrations at hatching. During growth, hypothalamic TRH concentrations further increased, whereas SRIH concentrations decreased. Both observations can, when accompanied by respectively an increased and decreased secretion rate, contribute to the increased circulating GH levels in up to 15-day-old chicks.

Plasma TSH indices dropped towards hatching. This observation is in contrast with the increase in thyrotropes after E10.5 (Thommes et al. 1983) and with the increase in TSH $\beta$ mRNA levels around E19 (Gregory et al. 1998). Posttrancriptional regulation may account for the presence of low plasma TSH levels (our data) along with increased TSH $\beta$ mRNA levels (Gregory et al. 1998). Since circulating $\mathrm{T}_{4}$ and $3,3^{\prime}, 5$-triiodothyronine concentrations increase prior to hatching (Darras et al. 1992), feedback mechanisms through thyroid hormones are likely to take part in this regulation (Gregory et al. 1998). While plasma TSH levels decreased, the availability of hypothalamic TRH increased towards hatching. Due to the huge increase this is probably accompanied by an increased TRH release. However, a negative correlation was observed. This is contradictory to the numerous data on a TSH-releasing activity of TRH during embryonic development ( $\mathrm{T}_{4}$ measurement - Thommes \& Hylka 1978, Thommes et al. 1984, Kühn et al. 1988b). TRH is, however, not the sole stimulator of TSH release in the chicken. Ovine $\mathrm{CRH}$ acts both in the embryonic and the newly hatched chick as a potent TSH regulator (TSH index measurement - Geris et al. 1995, 1996). Further research is needed to clarify if this hormone plays a more important role in the control of plasma TSH levels in the embryonic chick. Other data showed that SRIH lowers the circulating $\mathrm{T}_{4}$ concentration in E18 but not in E16 chicks (Iqbal et al. 1989). At the same period in embryonic development we observed a twofold increase in hypothalamic SRIH concentrations, so a regulatory action of SRIH on plasma TSH levels cannot be excluded. Posthatch, both the increase in TRH and the decrease in SRIH may result in the observed constant elevation of circulating TSH towards adulthood. 


\section{Acknowledgements}

The skilful technical assistance of Mrs Voets, Ms Noterdaeme and Mr Van Ham is gratefully acknowledged. The authors wish to thank Dr T J Visser and Dr G S G Spencer for the gift of the TRH and the SRIH antiserum respectively. K Geris, V Darras and L Berghman were supported by the Fund for Scientific Research, Flandres.

\section{References}

Ambrosi G, Nicolardi G, Rizzi A, Lamosso ME, Benagiano V, Arena R \& Fanelli F 1992 Further data on the development of SRIF-like immunoreactive nerve cell populations in the chick embryo brain stem: I. Medulla and pons. Boll. Soc. It. Biol. Sper. 68 321-328.

Berghman LR, Darras VM, Chiasson RB, Decuypere E, Kühn ER, Buyse J \& Vandesande F 1993 Immunocytochemical demonstration of chicken thyrotropes and development of a radioimmunological indicator for chicken TSH using monoclonal and polyclonal homologous antibodies in a subtractive strategy. General and Comparative Endocrinology 92 189-200.

Blahser S \& Heinrichs M 1982 Immunoreactive neuropeptide systems in avian embryos (domestic mallard, domestic fowl, Japanese quail). Cell and Tissue Research 223287.

Darras VM, Visser TJ, Berghman LR \& Kühn ER 1992 Ontogeny of type I and type III deiodinase activities in embryonic and posthatch chicks: relationship with changes in plasma triiodothyronine and growth hormone levels. Comparative Biochemistry and Physiology 103A 131-136.

Darras VM, Finné M-F, Berghman LR \& Kühn ER 1994 Ontogeny of the sensitivity of the somatotrophs to thyrotrophin-releasing hormone (TRH) and growth hormone-releasing factor (GRF) in the embryonic and posthatch chick. Annales d'Endocrinologie $\mathbf{5 5}$ 255-260.

Dean CE, Piper M \& Porter TE 1997 Differential responsiveness of somatotrophs to growth hormone-releasing hormone and thyrotropin-releasing hormone during chicken embryonic development. Molecular and Cellular Endocrinology 132 33-41.

Decuypere E \& Scanes CG 1983 Variation in the release of thyroxine, triiodothyronine and growth hormone in response to thyrotrophinreleasing hormone during development of the domestic fowl. Acta Endocrinologica 102 220-223.

Fuse Y, Polk DH, Lam RW \& Fisher DA 1991 Ontogeny of thyrotropin-releasing hormone and precursor peptide in the rat. Pediatric Research 30 28-33.

Galton VA \& Hiebert A 1987 The ontogeny of the enzyme systems for the $5^{\prime}$ and 5-deiodination of thyroid hormones in the chick embryo liver. Endocrinology 120 2604-2610.

Geris KL, Darras VM, Berghman LR \& Kühn ER 1995 Influence of corticotropin-releasing factor on the in vitro thyroxine and thyrotropin secretion in newly hatched fowl. Belgian Journal of Zoology 125 143-156.

Geris KL, Kotanen SP, Berghman LR, Kühn ER \& Darras VM 1996 Evidence of a thyrotropin-releasing activity of ovine corticotropinreleasing factor in the domestic fowl (Gallus domesticus). General and Comparative Endocrinology 104 139-146.

Gregory CC, Dean CE \& Porter TE 1998 Expression of chicken thyroid-stimulating hormone $\beta$-subunit messenger ribonucleic acid during embryonic and neonatal development. Endocrinology 139 474-478.

van Haasteren GAC, Linkels E, Klootwijk W, Van Toor H, Rondeel JMM, Themmen APN, De Jong FH, Valentijn K, Vaudry H, Bauer K, Visser TJ \& de Greef WJ 1995 Starvation-induced changes in hypothalamic content of pro-thyrotropin-releasing hormone (proTRH) mRNA and the hypothalamic release of pro-TRH derived peptides: role of the adrenal gland. Journal of Endocrinology 145 143-153.

Harvey S, Lam S-K \& Hall TR 1986 Somatostatin tonically inhibits growth hormone secretion in domestic fowl. Journal of Endocrinology 111 91-97.

Hylka VW, Tonetta SA \& Thommes RC 1986 Plasma iodothyronines in the domestic fowl: newly hatched to early adult stages, with special reference to reverse triiodothyronine $\left(\mathrm{rT}_{3}\right)$. Comparative Biochemistry and Physiology 84A 275-277.

Iqbal A, Kühn ER \& Decuypere E 1989 Somatostatin inhibits thyroxine release from the thyroid gland of chick embryo. Medical Science Research 17 427-428.

Jansson J-O, Ishikawa K, Katakami H \& Frohman LA 1987 Pre- and postnatal developmental changes in hypothalamic content of rat growth hormone-releasing factor. Endocrinology 120 525-530.

Josza R, Vigh S, Mess B \& Schally A 1986 Ontogenetic development of corticotropin-releasing factor (CRF)-containing neural elements in the brain of the chicken during incubation and after hatching. Cell and Tissue Research 244 681-685.

Kühn ER, Decuypere E, Iqbal A, Luysterborgh D \& Michielsen R 1987 A comparison between the thyrotrophic and peripheral activities of thyrotrophin and thyrotrophin-releasing hormone in the chick embryo and adult chicken. Medical Science Research $\mathbf{1 5}$ 431-432.

Kühn ER, Decuypere E, Huybrechts L \& Darras VM 1988a Control of the peripheral monodeiodination in the chicken. In Programme of the IV International Symposium on Avian Endocrinology, Tokyo. July 26-29, pp 36-37. Eds S Ishii \& M Wada.

Kühn ER, Decuypere E, Iqbal A, Luysterborgh D \& Michielsen R $1988 b$ Thyrotropic and peripheral activities of thyrotrophin and thyrotrophin-releasing hormone in the chick embryo and the adult chicken. Hormone and Metabolic Research 20 158-162.

Lam S-K, Harvey S \& Scanes CG 1986 Somatostatin inhibits thyroid function in fowl. General and Comparative Endocrinology 63 134-138.

Lamberton RP, Lechan RM \& Jackson IM 1984 Ontogeny of thyrotropin-releasing hormone and histidyl proline diketopiperazine in the rat central nervous system and pancreas. Endocrinology 115 2400-2405.

Nemeskeri A, Grouselle D, Faivre-Bauman A \& Tixier-Vidal A 1985 Developmental changes of thyroliberin (TRH) in the rat brain. Neuroscience Letters 53 279-284.

Oliver C, Eskay RL \& Porter JC 1980 Developmental changes in brain TRH and in plasma and pituitary TSH and prolactin in the rat. Biology of the Neonate 37 145-152.

Piper MM \& Porter TE 1997 Responsiveness of chicken embryonic somatotropes to somatostatin (SRIF) and IGF-I. Journal of Endocrinology 154 303-310.

Preisner CM, Klee GG, Scheithauer BW \& Abboud CF 1990 Free alpha subunit of the pituitary glycoprotein hormones: measurement in serum and tissue of patients with pituitary tumors. American Journal of Clinical Pathology 94 417-421.

SAS Institute Inc. 1985 SAS User's Guide: Statistics Version, 5th edn, p 956. Cary, NC: SAS Institute Inc.

Scanes CG, Harvey S, Morgan BA \& Hayes M 1981 Effect of synthetic thyrotrophin-releasing hormone and its analogues on growth hormone secretion in the domestic fowl (Gallus domesticus). Acta Endocrinologica 97 448-453.

Shambaugh GE $3^{\text {rd }}$, Kubek M \& Wilber JF 1983 Characterization of rat placental TRH-like material and the ontogeny of placental and fetal brain TRH. Placenta 4 329-337.

Spencer GSG, Harvey S, Audsley ARS, Hallett KG \& Kestin S 1986 The effect of immunization against somatostatin on growth rates and growth hormone secretion in the chicken. Comparative Biochemistry and Physiology 85A 553-556. 
Spencer GSG, Berry C \& Johnston S 1991 Neuroendocrine regulation of growth hormone secretion in sheep. IV. Central and peripheral cholecystokinin. Domestic Animal Endocrinology 8 555-563.

Thommes RC 1987 Ontogenesis of thyroid function and regulation in the developing chick embryo. Journal of Experimental Zoology (Suppl 1) 273-279.

Thommes RC \& Hylka VW 1977 Plasma iodothyronines in the embryonic and immediate posthatch chick. General and Comparative Endocrinology 32 417-422.

Thommes RC \& Hylka VW 1978 Hypothalamo-adenohypophysealthyroid interrelationships in the chick embryo: I. TRH and TSH sensitivity. General and Comparative Endocrinology 34 193-200.

Thommes RC, Martens JB, Hopkins WE, Caliendo J, Sorrentino MJ \& Woods JE 1983 Hypothalamo-adenohypohyseal-thyroid interrelationships in the chick embryo: IV. Immunocytochemical demonstration of TSH in the hypophyseal pars distalis. General and Comparative Endocrinology 51 434-443.

Thommes RC, Williams DJ \& Woods JE 1984 Hypothalamoadenohypophyseal-thyroid interrelationships in the chick embryo: VI. Midgestational adenohypophyseal sensitivity to thyrotrophinreleasing hormone. General and Comparative Endocrinology $\mathbf{5 5}$ 275-279.

Thommes RC, Caliendo J \& Woods JE 1985 Hypothalamoadenohypophyseal-thyroid interrelationships in the developing chick embryo: VII. Immunocytochemical demonstration of thyrotrophin-releasing hormone. General and Comparative Endocrinology 57 1-9.

Received 13 February 1998 Accepted 9 June 1998 